\title{
HIGHLIGHTS
}

\section{Rangeland Ecology \& Management, May 2016}

\section{Evidence Targeted Grazing Benefits to Invaded Rangelands Can Increase over Extended Time Frames}

\section{Matthew Rinella and Susan Bellows}

Using simulations to improve grazing-based leafy spurge control, we compared a sheep grazing treatment (spurge and grass defoliated) to a cattle grazing treatment (only grass defoliated). Simulated sheep grazing defoliated leafy spurge either prior to or during flowering. Leafy spurge declined most dramatically where defoliated prior to flowering, even though defoliation during flowering removed greater leafy spurge biomass. The difference in cumulative effect of simulated sheep compared to cattle grazing increased over time. Simulated sheep grazing prior to flowering was most effective, reducing leafy spurge biomass production $74 \%$ and increasing grass biomass production $40 \%$ after eight years of treatment.

\section{Effects of Intermediate-Term Grazing Rest on Sagebrush Communities with Depleted Understories: Evidence of a Threshold}

\section{K. W. Davies, J. D. Bates, and C. S. Boyd}

Millions of acres of sagebrush (Artemisia spp.) plant communities have been degraded by past improper management resulting in dense sagebrush stands with depleted herbaceous understories. Rest from grazing is often suggested as a treatment to promote recovery of these communities. We found intermediate rest (5-6 years) increased perennial herbaceous cover, but did not change herbaceous vegetation densities, diversity, richness, litter, and biological soil crust. These results suggest that intermediate-term rest does not promote recovery of the herbaceous understory compared to moderate grazing in these communities.

\section{Effects of Using Winter Grazing as a Fuel Treatment on Wyoming Big Sagebrush Plant Communities}

\author{
K. W. Davies, A. M. Nafus, C. S. Boyd, A. Hulet,
} and J. D. Bates

Though winter grazing is a fuel treatment that can reduce wildfire severity and risk in Wyoming big sagebrush (Artemisia tridentata wyomingensis) communities, its impact on plant community characteristics is largely unknown. We evaluated the effects of repeated winter grazing by cattle for five to six years at utilization levels of 40-60\%. Winter grazed and ungrazed areas had similar vegetation characteristics, but grazing reduced herbaceous cover. Cover provides important habitat for some wildlife species. This study suggests that winter grazing can be applied without negatively impacting the native plant community; however, it should be strategically applied to reduce the possibility of adversely impacting wildlife.

\section{Livestock Use Has Mixed Effects on Slender Orcutt Grass in Northeastern California Vernal Pools}

Kyle E. Merriam, Meredith C. Gosejohan, Peter J. Weisberg, and Kirsten M. Bovee

Grazing has been considered a threat to rare species that inhabit springtime pools. We evaluated the effects of livestock use on the federally listed slender Orcutt grass (Orcuttia tenuis) in northeastern California. Livestock do not graze this plant, so effects of livestock are indirect. Livestock use may benefit slender Orcutt grass in some years by reducing litter accumulation, but in pastures where hoof print cover was high, including those grazed early in the season, livestock use had negative effects. By considering factors such as precipitation, site conditions, and season of grazing, land managers can balance the needs of sensitive 
vernal pool species with maintaining livestock utilization on public lands.

\section{A Potential New Herbicide for Invasive Annual Grass Control on Rangeland}

\section{Derek James Sebastian, James R. Sebastian, Scott J. Nissen, and K. G. Beck}

There is need for new downy brome (Bromus tectorum) management strategies that provide consistent long-term control without damaging co-occurring species. We compared indaziflam to glyphosate, imazapic, and rimsulfuron in terms of downy brome control and non-target impacts. In three different plant communities indaziflam provided better downy brome control than currently recommended herbicides two and three years after treatment, and resulted in only minimal negative impacts to the native perennial plants. Although a grazing tolerance for proper use of indaziflam still needs to be established, this study provides evidence of a new herbicide for residual downy brome on rangeland.

\section{Impacts of Imazapyr and Triclopyr Soil Residues on the Growth of Several Restoration Species}

Cameron H. Douglass, Scott J. Nissen, Paul J. Meiman, and Andrew R. Kniss

Herbicides are often employed for invasive plant control, but there is little data on the sensitivity of desirable plants to herbicide residues. We quantified degradation rates of imazapyr and triclopyr in six Colorado soils, and measured the sensitivity of nine species to the two herbicides. Imazapyr degraded much more slowly than triclopyr, and species were more sensitive to imazapyr. Degradation was more rapid in finer textured soils with higher organic matter and cation exchange capacity. Plant sensitivity to the herbicides was highly variable. We encourage managers to temporally stagger species seeding based on herbicide sensitivity, and prioritize sites with soils favoring rapid herbicide degradation.

\section{Seed Production and Seedling Fitness are Uncoupled from Maternal Plant Productivity in Three Aridland Bunchgrasses}

Rebecca E. Drenovsky, Megan L. Thornhill, Matthew A. Knestrick, Daniel M. Dlugos, Tony J. Svejcar, and Jeremy J. James

Maintaining self-sustaining populations of desired plants is fundamental to rangeland management, and understanding the relationships among plant growth, seed production, and seedling recruitment are critical to these efforts. We investigated how soil nutrient and water availability influenced maternal plant growth and seed production, as well as offspring growth and survival. Although maternal plant growth increased with soil resource availability, seed production and seedling survival were less responsive to these increases. Natural and anthropogenic driven changes in soil resource availability may alter plant community productivity, but these responses may not directly link to changes in seedling recruitment or community composition.

\section{Compensatory Photosynthesis, Water-use Efficiency, and Biomass Allocation of Defoliated Exotic and Native Bunchgrass Seedlings}

Erik P. Hamerlynch, Brenda S. Smith, Roger. L. Sheley, and Tony J. Svejcar

How small seedlings in semiarid rangelands respond physiologically to defoliation may be especially important to their successful establishment. We found that experimental clipping induced similar increases in photosynthesis in the remaining tissue in two sagebrush steppe bunchgrasses. However, this compensatory response resulted in increased water-use efficiency in the exotic species crested wheatgrass (Agropyron cristatum), while it declined in the native bluebunch wheatgrass (Psuedoroegnaria spicata). This is likely due to differences in relative aboveground and belowground growth. These results help explain why crested wheatgrass establishes so successfully from seed across a wide range of conditions in semiarid rangelands compared to bluebunch wheatgrass.

Characterizing the Response of Piñon-Juniper Woodlands to Mechanical Restoration Using High-Resolution Satellite Imagery

\section{A. J. H. Meddens, J. A. Hicke, and B. F. Jacobs}

In northern New Mexico, interactions between climate, land use, and reduction of surface fires facilitated the expansion of piñon-juniper (Pinus spp.-Juniperus spp) woodlands. Woodland expansion resulted in reduced herbaceous cover and increased soil exposure, leading to increased runoff and erosion. We quantified land-cover changes following mechanical treatment of piñon-juniper woodlands using preand post-treatment high-resolution satellite images. Our results demonstrate the utility and promise of high-resolution satellite imagery to inform rapid and objective assessments of landscape-scale restoration treatments.

\section{Vegetation Response to Piñon and Juniper Tree Shredding}

Jordan Bybee, Bruce A. Roundy, Kert R. Young, April Hulet, Darrell B. Roundy, Leann Crook, Zachary Aanderud, Dennis L. Eggett, and Nathan L. Cline

Piñon (Pinus spp.) and juniper (Juniperus spp.) tree expansion and infilling in sagebrush steppe communities 
decreases shrub and perennial herbaceous cover and increases woody fuel loads. We measured the effects of tree shredding on 44 sites in Utah from low to high pretreatment tree cover. Perennial herbaceous cover increased 11\% (20.1\% cover) when trees were shredded at 15-90\% tree cover. Because shrub cover decreases by half when tree cover is $\geq 20 \%$, shredding at earlier phases of infilling will best maintain mixed shrub-perennial herbaceous communities.

Rangelands (38)3:155-157

doi: 10.1016/j.rala.2016.04.001 